\title{
Institutional Transformation of the Al-Birr College as a form of Regeneration Scholars in University of Muhammadiyah
}

\author{
Muhammad Ali Bakri \\ Doctoral Student in Alauddin Islamic State University, \\ Makassar \\ Azhar Arsyad \\ Lectures Alauddin Islamic State University, \\ Makassar \\ Muhammad Khalifah Mustami \\ Lectures Alauddin Islamic State University, \\ Makassar \\ Muhammad Yaumi \\ Lectures Alauddin Islamic State University, \\ Makassar
}

\begin{abstract}
This study aims to describe and analyze institutional transformation of the Al-Birr college as a form of Regeneration Scholars in University of Muhammadiyah Makassar, which includes aspects of (1) institutional management, (2) institutional transformation process and (3) output of Al-Birr college institutional transformation in University of Muhammadiyah Makassar. This type of research is descriptive qualitative research through phenomenological approaches. Data collection techniques using open interviews, observation and documentation studies. Determination of data sources was done purposively with data analysis techniques namely data reduction, data presentation, and drawing conclusions and verification to analyze data. The results showed that (1) the implementation institutional management of Al-Birr college in aspects of leadership management, educators, student affairs, curriculum, learning systems, infrastructure and financial systems, had fundamentally and substantially achieved organizational goals with effective and efficient. This institutional management system produces a unique management design in managing educational and dakwah (Da'wah literally means "issuing a summons" or "making an invitation", Tabligh literally means 'to convey'. Contextually, it refers to conveying the message of Islam) institutions as educational models oriented to philanthropy or charity project. College institutional management is generally carried out centrally and autonomously under the supervision of the Asia Muslim Charity Foundation in Jakarta. (2) the process of college institutional transformation refers to the background of the establishment, vision, mission, goals, structure, and organizational culture that results in the strategic program to produce Ulama in University of Muhammadiyah Makassar. Strategic program of Al-Birr college are training and sending da'I (Ulama) in remote areas, Alquran memorizing school, syariah and dakwah programs and integration program for Ulama Tarjih Muhammadiyah (PUTM). (3) the output of institutional transformation has resulted many graduates and da'is who have roles in providing guidance and effective community service.
\end{abstract}

Keywords: Transformation, institution, regeneration 


\section{INTRODUCTION}

Arabic education programs and Islamic study (Ma'had) is one of the model institutions of alternative education in the persyarikatan Muhamadiyah (The Islamic mass Organization in Indonesia) who is able to respond to the scarcity of scholars by preparing a cadre of scholars through education programs Arabic language and Islamic Studies. Ma'had expected to be a regeneration of the preachers and ulama (meaning a person who engages in claim (calling or inviting others to Islam)), and is committed to raising, developing, and together advancing the charitable efforts of Muhammadiyah.

The cadre of scholars through the ma'had also oriented to be able to fill the shortage of cadres, as well as make dynamic stretching dakwah commanding the good and forbidding the evil (amar makruf nahi mungkar) and the spirit of tajdid Muhammadiyah (Renewal). Regeneration of Ulama certainly can not be done instantaneously, but must be planned, programmed holistically integrative, and professionally managed with institutional management that is accountable, transparent, trustworthy, and modern. Regeneration scholars of intellectual property through ma'had oriented to be able to strengthen the quality and quantity of the Muhammadiyah cadre of (The Islamic mass Organization in Indonesia) in the future.

The transformation of Ma'had's institution is a necessity in carrying out its function as an institution of education and da'wah. Transformation in the context of an organization means fundamental and large-scale change. Transformation emphasizes a change in form, but includes the idea of remodeling, modification, and restructuring ( $\mathrm{Du}$ Preez, et al., 2016). Transformation emphasizes form change, which includes ideas or ideas from reshaping, modifying and restructuring. Transformation also means change (form, character, function, etc.), in Arabic known as tahawwala, yatahawwalu, tahwilan. Renewal is an effort to reorganize established, outdated social, political, educational and scientific structures, including the institutional structure of Islamic education ( $\underline{\text { Azra, 1999)}}$.

Implementation of organizational transformation, empowerment of human resources, and management of management information systems is a reflection of learning organizations, because learning organizations where people continually expand their capacity to create results are truly desirable, where new and expansive patterns of thinking are guaranteed, where collective aspiration is free, and where people are continually learning to see the whole together ( $\underline{\text { Sange, 1991)}}$.

Organizational transformation refers to the formation of a vision, culture, strategy and organizational structure that has an impact on the quality of education. The quality of education has significant relevance to organizational transformation, empowerment of human resources, and management of management information systems (Yaumi \& Damopolii, 2015). Al-Birr college (Ma'had) as an education and da'wah organization is expected to be able to transform into a learning organization in producing ulama cadres at the University of Muhammadiyah Makassar. The study of learning organizations has developed rapidly in various studies including those used in the study of educational organizations. The leaders of educational organizations currently think of efforts to improve work productivity of employees and organizational management, so that they have the ability to compete and adapt towards rapid changes in the era of industrial revolution 4.0.

Al-Birr college (Ma'had) as an Islamic da'wah organization in carrying out its vision, mission, goals, strategies, culture, and organizational structure requires good leadership and management to become a learning organization and can make changes and dynamics of the entire education program. Ma'had as an educational institution needs to develop managerial 
capabilities as part of leadership that will bring change to the organization. From the above understanding it can also be developed a conception of the concept of the Caliph who implements that humans have the task or carry out missionary mission to prosper the earth which requires a good managerial management. This is written in Holy Quran.

"And it is He who has made you successors upon the earth and has raised some of you above others in degrees [of rank] that He may try you through what He has given you. Indeed, your Lord is swift in penalty; but indeed, He is Forgiving and Merciful ( $\underline{\text { Al- }}$ An'am 6.165)"

Dakwah is one of the instruments of upholding Islam which is imposed on the people both individually and organizationally (Hafidhuddin, 1998). The changing times demand changes in the da'wah strategy. Society as an object as well as the subject of da'wah from time to time continues to experience change, in various dynamics both in terms of behavior and mindset. Social change occurs when there is a willingness of community members to abandon the old elements of culture and social systems and begin to switch to using new social systems (Bungin, 2009).

In a historical perspective, Islamic law was revealed to change society and humanity from the previous condition of ignorance towards the creation of a civil society order illuminated by religious values. In this context, it can be understood that the change strategy adopted by Allah as a Shari'a is a gradual (gradual) strategy, slowly and surely in the context of management theory or social change theory, namely changes that occur gradually, gradually and within a period of time long. There are five things that must be considered in the transformation of educational institutions, namely Islamic education institutions must increase competitiveness seriously and planned, so that they are competent in international relations; open various study programs; must strengthen critical functions and future oriented (future oriented); must carry out accountability and must carry out continuous and continuous evaluations so that quality assurance can be accounted for (Ramayulis, 2008).

The development of the education system requires the institutional transformation of Al-Birr college (Ma'had) which is expected to encourage the improvement of the quality and quality of the education system through institutional integration under the Muhammadiyah Higher Education (PTM) which has a more developed institutional base. The University of Muhammadiyah Makassar is the largest PTM and charity business Muhammadiyah in South Sulawesi has responsibility in the efforts of cadre cadres through the Ulama Tarjih and Ma'had Al-Birr Education program with the aim of producing graduates who are noble, capable, professional, responsible and independent.

The focus of this study is ma'had's institutional transformation as a forum for the regeneration of scholars at the University of Muhammadiyah Makassar, which includes management of the ma'had institution, the process of institutional transformation (Ma'had) and the output of institutional transformation ma'had in producing cadres of Ulama. The research questions are described in three sub-problems as follows:

1. How is the implementation of the Al-Birr college (Ma'had) institutional management at the University of Muhammadiyah Makassar?

2. What is the process of institutional transformation of Al-Birr college (Ma'had) at the University of Muhammadiyah Makassar?

3. What are the outputs and outcomes of institutional transformation of Al-Birr college (Ma'had) at the University of Muhammadiyah Makassar? 


\section{Transformation and Change of Organizations}

\section{LITERATURE REVIEW}

Transformation emphasizes a change in form, but includes the idea of 'remodeling, modification, and restructuring (du Preez et al., 2016). Transformation can occur intentionally and unintentionally. Deliberate transformation is characterized by planning, clear management, and indicated by the existence of programs and expected changes clearly. Deliberate transformation is usually programmed by a community agent to change ideas, concepts, cultures that exist in society from less pleasant (good) to good (pleasant). Whereas accidental transformation is a change that occurs naturally (both due to changes in natural conditions, technology and so on). This change can occur because of the influence of the community itself as well as the influence from outside the community (Nayoan \& Mandey, 2011).

Three stages of the planned change model are unfreezing, changing or cognitive restructuring, and refreezing. Unfreezing or searching is a stage that focuses on creating motivation to change. Individuals are encouraged to change old behaviors and attitudes with what management wants. (1) Unfreezing is a change effort to overcome individual resistance and group suitability. The search process is a force between the driving factors and barriers to changes in the status quo. (2) Changing or cognitive restructuring is the learning stage where members of the organization are given new information, new behavioral models in seeing things. That is to help organizational members learn concepts or new points of view. (3) Refreezing is a stage where changes occur stabilized by helping members integrate behaviors and attitudes that have changed into normal ways of doing things (Lewin, 1940; cited in Renald Kazali, 2006).

The development of the institutional organization of Al-Birr college (Ma'had) is a strategy and effort in perfecting the education system carried out in a planned manner in a comprehensive function related to the value and structure of its institutional organization. The approach in developing this organization uses a situational or contingency approach to improve organizational effectiveness. The development of this institutional model places more emphasis on the system as the target of change. The steps to be taken are through a process that includes a series of systematic change planning that is carried out continuously. This is written in Holy Quran.

"It is the same [to Him] concerning you whether one conceals [his] speech or one publicizes it and whether one is hidden by night or conspicuous [among others] by day (Al Raad 13.11)"

The results of research conducted by Yaumi \& Damopolii (2015)provide evidence that organizational transformation includes vision, culture, strategy and structure. The work culture developed is shared learning, teamwork, awareness to progress, regeneration, communication, and building trust. The strategy developed in helping smooth the task and responsibility is to revise learning all scientific fields, increase work motivation, manage time to study and work, maximize learning in accordance with the field of expertise. There is a tendency for some traditional Islamic boarding schools to develop modern education systems that have an impact on changes in the curriculum system and educational institutional aspects that are tailored to the demands of the government (Zarkasyi, H. F., 2015).

The main key for an organization to exist in the face of organizational change is the leadership style in developing the organization's vision and mission. There are six variables measured in 
organizational development, namely organizational goals, organizational structure and relationships, leadership, rewards and work order mechanisms (Hardiansyah, 2010).

\section{Organizations and educational institutions}

The terms institutional and organizational are often confusing and interchangeably. Recent developments, institutional terms are more often used for meanings that include both at once. Institutions are preferred because the word organization refers to a social form formal. The institutional word is also preferred because it gives a more social impression and more respect for local culture (Uphoff, 1986).

The concept of "institution" or "institution" sociologically is a set of normative relationships that contain beliefs and values that are centered on social needs which are the drivers of the emergence of actions that become social traditions. Institutions are traditional behavior patterns that are strong and valued by society. The concept of institutions is equated with the concept of organization. Institutional is a structural system consisting of a number of people

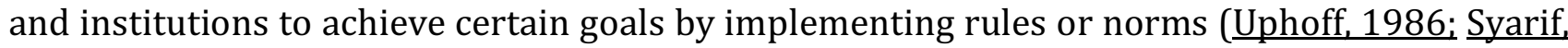
$\underline{2013})$.

The realization of a good, effective, efficient and appropriate educational organization must be based on organizational principles, namely the principle of organizational goals, unity of purpose, unity of command, range of control, delegation of authority, efficiency, principle of sustainability and coordination (Rusdiana, 2016). The principles of the organization were simplified by Arsyad, (2012) with several organizational principles, namely the division of labor, discipline, unitary unity, unity of direction, shared interests over personal interests, tiered ranges and ranges of control ( $\underline{\text { Arsyad, 2012) }}$.

The organization of educational institutions into two, namely macro and micro organizations. Macro education organizations are educational organizations seen in terms of organizations broadly on a national scale. The micro education organization is an educational organization seen with a starting point with existing units in an educational institution that organizes the teaching and learning process directly (Nurhadi, 2003).

Islamic education characteristics cover all aspects of human life, both in the form of physical, mental, aesthetic, moral, emotional, aesthetic, and social aspects. Islamic education intends to achieve happiness to live in the world and the hereafter equally and equally. Islamic education develops all human activities in their interactions with others, by applying the principle of integrity and balance. Islamic education is carried out continuously and continuously indefinitely. Islamic education through the principles of integrity, universal, and balance (Toto Suharto \& Shaleh, 2006). Based on the scope and characteristics of Islamic education is needed government policies and maximum efforts of Muslims themselves, especially from figures of Islamic education, to reform Islamic education, both in terms of scientific epistemology and institutions without disregarding other educational components, such as goals, curriculum, teaching methodology, education staff ( teacher and lecturer), and management.

The definition of Islamic education characteristics mentioned above are very relevant and in accordance with the principles and objectives of education developed in Ma'had. The series of characteristics of education possessed by Ma'had is to have a goal, namely the ability to develop so that it is useful for the benefit of society. To achieve that goal, the educational process is carried out in a planned manner by selecting the appropriate content, strategies, and assessment techniques. The purpose of education is to develop the potential of students to have religious spiritual strength, self-control, personality, intelligence, noble character, and 
skills needed by themselves and society. Differences in education in general with Islamic education can be identified through the goals to be achieved. If the goal of National education is only concerned with the formation of a person for the happiness of the world, Islamic education is more than that, namely to reach the hereafter happiness (Muljono Domopolii, $\underline{2011})$.

The purpose of Islamic education is inseparable from the purpose of human life in Islam, namely to create personal servants of Allah who are always fearful of Him, and can achieve a happy life in the world and in the hereafter (Azyumardi Azra, 2012).

Learning organizations are organizations that all members continue to improve their ability to achieve expected performance. Learning organization is an organization where new thinking is always valued and developed. Learning organizations are all aspirations of individual members and groups given freedom. Learning organizations are organizations whose members learn together on an ongoing basis or lifelong learning. Learning organisasi are organisasi where people continually expand Reviews their capacity to create the results they truly desire, where new and expansive patterns of thinking are nurtured, where collective aspiration is set free, and where people are continually learning to see the whole together (Peter M. Senge, 1990).

The findings of previous researchers provide evidence that Islamic education institutions must be prepared and ready to make changes due to various factors and threats. So Islamic education institutions should make changes when the institution still exists to improve its quality and existence as well as its competitiveness in society and the world of education today (Efendi, N. 2014).

Learning organization) in a community organization is needed especially in the development of human resources, the importance of mutual understanding of the organization's vision and mission in Team learning. The implementation of the learning organization concept is able to improve organizational performance with growth and sustainability in every activity. However, not all organizations are able to create growth and maintain the sustainability of their activities (Syafrilenti, 2006).

\section{Ma'had as a Cadre Education Institute for Ulama}

Ma'had is interpreted as an institution, institute or body (Manżūr, 2003). In Indonesia, the word ma'had is generally used for Islamic education institutions, such as Islamic boarding schools. In principle the embedding of the meaning of ma'had in Islamic education institutions is appropriate because in the institution (boarding school) the students live in a dormitory (cottage) and are committed to forge themselves by studying earnestly in order to demand knowledge, especially science Islamic science (Mastuhu, 1994).

Al-Birr college (Ma'had) functions as a cadre organization of scholars who are oriented towards deepening Islamic sciences. Ma'had's main role in global competence is to educate the public and improve national competitiveness, care for Indonesian Islam and maintain the beauty of Indonesian Islam that is peaceful, tolerant and democratic and transforms religious knowledge into everyday behavior (Amin Kamaruddin, 2016). Ulama have a central role in the midst of the life of the people, to continue the prophetic treatise after leaving, the people give very serious attention to the existence and quality of scholars. The importance of the position of ulama in the midst of the people today, has consequences, that they should seriously consider a program of cadre and empowerment of scholars. Ulama are heirs of the prophet who continue the role of the Prophet as the guardian and bearer of the message of God to be conveyed to mankind. 
Ulama are religious leaders and devotees, who have a characteristic form of scientific depth and height. Appearing as a role model, especially in terms of sincerity, simplicity, and dedication in guiding the people to the right path.

Morally and shari'ah, scholars carry out several functions as stated in the Qur'an, namely: tablig (conveying religious messages) that touches the heart and stimulates practice. Normatively, ulama are believed to be the heirs of the prophets whose messages and actions are recognized as authentic religious representations and missions. However, the role of scholars in reality cannot be excluded from the ever-changing social development and demands the quality of ulema that is in accordance with the challenges of the times. Therefore, its position in the social, political and cultural structures of society is dynamic and varies from time to time and between one region and another (Ismail R. Alfaruqi dan Lois Lamya Al-Faruqi. $\underline{2003})$.

The results of previous studies conducted by Zainiyati (2015) provide evidence that the integration of Ma'had Sunan Ampel Al-Aly into the education system has a positive impact on the development of the vision and mission of institutional organizational goals. The organizer of Ma'had Aly (Sengkang As'adiyah Islamic Boarding School and DDI Mangkoso Islamic Boarding School) as a special program for ulama cadre printers experienced many limitations in terms of institutional management and implementation of educational curricula such as limited financial support, limited facilities and infrastructure, limited development and implementation integrated and integrated learning management. This has an impact on the low interest of the community to continue their education in the future (Idham \& Sadli Mustafa, 2016).

Madrasas are transformed from religious education institutions into schools that are characterized by Islam. In the new status the madrasa must work hard to meet the demands of stakeholders, through (1) management capacity, (2) curriculum, (3) limited human resources, (4) academic orientation, (5) national examinations, (6) regional autonomy (Supaat, S., 2011).

\section{Cadreation of The Muhammadiyah Ulama}

Cadre formation is a structured effort to form a cadre in an organization that usually follows a certain syllabus. Cadre formation is a process carried out by organizational cadres in realizing the organization's vision and mission. Muhammadiyah is an Islamic movement and preaching amar ma'ruf nahi munkar and continues to equip and expand superior and qualified cadres to become the executor and executor of the ideals of Muhammadiyah oriented to the formation of the true Islamic community. The meaning of the Islamic movement means that Muhammadiyah is always illuminated and in the spirit of the teachings of Islam, while the missionary movement has the meaning of Islamic teachings that are understood to be practiced and preached to the public.

Both of these heavy tasks cannot be carried out by ordinary citizens and ordinary people, these tasks must be held by the people prepared, and that is what is called the cadre of scholars who in the future will become scholars, the people most responsible for developing and preaching responsibilities this straight teaching of Islam. One of the future of Muhammadiyah is determined by the system of values and organizational culture and the quality of its cadres.

Value system based on the Koran and the Sunnah. Built on the ideological foundation of the Muhammadiyah movement. Business charity management procedures oriented to cadre power Forming ulama cadres who have good abilities is not as easy as turning hands, must begin with desires (himmah qawiyah), sincerity of Muhammadiyah leaders, program 
management capacity and lecturer capacity and availability of funds and facilities / infrastructure needed. The direction and policies of the ulama cadre program can be realized when the vision, mission and goals are desired. In addition, to optimize, vision, mission and competence, PUTM is also highly recommended to collaborate and synergize with related study programs at Muhammadiyah universities, and work together with Ma'had AMCF (Ma'had cooperation with Muhammadiyah Central Leaders withFoundations AsianMuslim Charity Foundation) (Iu Rusliana, 2018).

The function and position of cadres in an organization, the Muhammadiyah united is very important, because cadres can be said to be the core of the movement of the organization. In addition, cadres are also an important condition for the ongoing regeneration of leadership. For an organization, regenerating a healthy leadership is supported by the existence of qualified cadres, besides making the organization move dynamically, also the formation of its leadership will be fresh and energetic. The existence of cadres for Muhammadiyah with their qualifications and competencies seems to manifest the best creation of Allah SWT. This is written in Holy Quran

"You are the best nation produced [as an example] for mankind. You enjoin what is right and forbid what is wrong and believe in Allah. If only the People of the Scripture had believed, it would have been better for them. Among them are believers, but most of them are defiantly disobedient (QS. Ali Imran, 3: 110)".

The most important aspects that need to be developed in Islamic boarding schools include the institutional and organizational aspects, aspects of the curriculum, aspects of teaching methodology, aspects of the function and role of pesantren. All of these aspects have great influence and implications for the renewal and modernization of the education system in Islamic boarding schools, but the traditional aspects must still be maintained because it has been a tradition since the beginning of the establishment of Islamic boarding schools (Rama, 2003).

There are several aspects that must be considered in the management of modern boarding schools, namely (1) the purpose of pesantren education is dynamic, (2) institutional and organizational transformative patterns, (3) flexible patterned pesantren curriculum, (4) innovative-elective teaching methodology, (5) teachers or religious teachers are professional in style (Muljono Domopolii, 2011).

The effectiveness of the al-'Arabiyyah li al-Jamī books can help in improving the ability to speak Arabic (listening skills, reading skills, speaking skills and writing skills) of students (AlBirr college (Ma'had)). The cadre regeneration pattern carried out by Al-Bugisi has many similarities in the pattern of development developed in the community so that this study reinforces the side of the ulama cadre development model, especially in the education manhaj based on yellow books (Muchtar, 2016).

\section{METHODS}

The type of research uses descriptive qualitative research, namely research that describes the characteristics or characteristics of an individual, condition, symptom or certain group based on the phenomenon of the problem seen comprehensively and deeply ( approach used in this study is a phenomenological approach that seeks to understand, understand and observe in depth the setting of situations and conditions that occur in the management of Arabic education programs and Islamic studies (Ma'had), then interpret, interpret phenomena and events that occur according to the process Ma'had's institutional 
transformation as a forum for cadre regeneration. The important thing to be achieved from this type of qualitative research is to get a real picture of the interrelations of the informants' views, attitudes, behaviors, and activities in making management and institutional transformation so that they can produce cadres of Ulama.

This research was conducted at Al-Birr college (Ma'had) at the University of Muhammadiyah Makassar. Al-Birr college (Ma'had) is an institution of Arabic Language and Islamic Studies which has been established since 1996 under the guidance of the Asia Muslim Charity Foundation (AMCF) and the result of collaboration with the Central Leadership Muhammadiyah. Determination of informants is done purposively, which is chosen with certain considerations and objectives. The researcher chooses the informant based on: (1) the position and authority possessed, (2) knows or masters well the problem under study, (3) is directly involved with the object of research. Based on these criteria, the informants in question are the leaders of AMCF, University, Ma'had, Deans, Lecturers, Da'I (Ulama) and Students.

\section{RESULTS \\ Al-Birr college (Ma'had) Institutional Management}

Institutional management is a managerial technique for implementing changes to improving quality and better quality of the organization. Ma'had institutional management aims to conduct a systemic arrangement or fundamental and substantive organizational reform to achieve educational goals effectively and efficiently. Discussing institutional management is always related to the education management system which consists of planning, organizing, implementing and monitoring. In each educational institution the components of education consist of systems, lecturers, students, alumni, budgets and educational facilities. The overall utilization of the components of education will be achieved if it is managed productively through an effective and efficient education management system. The development of Ma'had in Indonesia is generally controlled by a figure or figure where the success of a Ma'had depends on public trust in the figure and reflects the number of students studying at the institution; educational institutions are usually managed with traditional management models which means that all decisions must be based on the figure.

These figures are religious leaders who lack management and administrative skills; generally the teachers who teach at the end are temporary teachers and several other teachers also teach in several different schools and different curricula. This can result in the quality of teaching being very low especially for teachers who teach more than one syllabus with different levels of ability and socio-cultural background of students; and generally educational institutions develop their own curriculum where people who are given assignments in developing curriculum / syllabus are also not competent in compiling the curriculum needed by Ma'had. Ma'had's institutional management is generally carried out centrally and autonomously under the supervision of AMCF together with The University of Muhammadiyah Makassar. The role of AMCF is very dominant in planning, organizing, directing and overseeing the institutional management system that is based on the central management system (CMS) which is made as the standard for implementing education management for all AMCF events in Indonesia. The institutional management system carried out at Al-Birr was described as follows:

\section{Leadership Management}

A leader must be able to carry out the task of leadership trust, maintain and account for it. As the leader of Ma'had who always tried optimally to follow the characteristics of the leadership of the Prophet. that is; sidiq, amanah, fathanah and tabligh. The leadership model presented by the director (Mudir) to Ma'had is oriented to the model of charismatic leadership. This type of 
leader has the ability to equalize the vision of the future with his subordinates, and enhance the needs of subordinates at a higher level than what they need. The concept of leadership is in line with the results of Zuhdi, MH (2014) that the ideal leadership concept in Islam is the prophetic leadership model. The Prophet is considered to be the most important example of leadership among many models of leadership in the history of mankind. According to him, this prophetic model of leadership can be used as an inspiring role model for the concept of leadership that is dignified, masculine, and holistic. the ideal Islamic leader is not a legacy, which is hereditary. A leader must get support and recognition from the majority of the community, and always prioritize the principle of deliberation in making decisions.

\section{Management of educators and education personnel}

The success of an educational institution is largely determined by the quality of its students. Therefore, it is important for educators (ustadz) to have academic qualifications and competencies that are good in the learning process especially in the fields of Arabic and Islamic studies. Academic qualifications and the competence of an ustadz in teaching greatly influence the learning objectives. Based on the results of interviews with one of the instructors (cleric) at Ma'had that they are the spearhead in achieving graduates who are qualified and competitive. No matter how sophisticated advances in technology today, the teaching role (ustad and ustadzah) remains important and has never been replaced, especially the learning model developed in the future is highly dependent on the teacher's ability to explain each material in Arabic. However, the current condition of learning in Ma'had is still dominated by ustadzah in the learning process which has so far been more of a teacher center learning, this condition needs to be replaced by student center learning.

The aim is that there is independence of students for independent learning and reducing the level of dependence on religious teachers. In addition, an ustadzah must be a role model and leader in the class. As a role model, religious teachers are expected to have moral and intellectual integrity so they are able to become role models. As class leaders, the main tasks of the ustadzah are facilitators who provide direction, enlightenment, and motivate students. Educators are the spearhead for the success of educational goals. Educators who love their duties, have the spirit and spirit of high idealism, are dedicated and have strong moral integrity, have managerial skills and are able to be role models in everything for their students. They must be prepared in such a way as to be able to adjust to the changes that occur by constantly improving themselves and renewing knowledge, being open to new things (open mind) and being willing to helpful (Perdana, N. S.,2015).

The role of Ustadz is not only as a daily learning provider standing in front of the class to present the material, but also as a developer of learning materials. This role is highly expected to be carried out because the ustadz are very comprehensive in understanding the students. Ustadz needs to understand the characteristics of students, goals, learning strategies, assessment instruments, learning materials, and good evaluation techniques. If each cleric realizes the importance of duties and responsibilities in the implementation of learning and is willing to carry out these responsibilities, the learning process will run effectively and efficiently, which ultimately can improve the quality of education as expected. The role of the teaching staff was delivered by the director of Ma'had (Mudir), that the role of an ustadz as an educator in ma'had is someone who has professional learning competencies in accordance with his field. Ustadz is one of the most important learning resources because he will give direction, foundation and scientific development for students. The process of developing human resources, namely through intense training, is very influential on improving human resources which aims to create professional teachers. The training needed is training that is tailored to the needs of training that refers to the demands of teacher competence. The training 
carried out aims to revive the performance that has decreased. The obstacle in the development of human resources is the unevenness of teachers who take part in training and lack of knowledge of teachers in the field of information technology (Mudassir, M., 2016).

\section{Student management system and hostel}

The Ma'had institution plays an important role in the regeneration process of Ulama. They are an integral part that is inseparable in the Ma'had institutional system which greatly influences the quality and quality of graduates that will be produced through the learning process carried out. The seriousness and seriousness of students following the entire educational process organized by Ma'had will accelerate the regeneration process of Ulama. The results of interviews with several students at Ma'had said that the reason they chose Al-Birr college (Ma'had), that the learning process at Al-Birr college (Ma'had) had given me a lot of meaningful progress in exploring Al-Islam became my goal in coming to study in Indonesia. Indonesia is a country that has a superior Islamic education system compared to my own country. The learning system with an introduction to Arabic in class is a distinct advantage for students in Ma'had that is different from other universities in Indonesia.

The Bachelor program in Ma'had is a continuation of the I'dad program with a higher level of scientific deepening with better quality and quality. Resolving the problems faced by Ma'had related to student affairs, that the management of Ma'had always coordinates with the AMCF education coordinator to obtain advice and input as well as appropriate solutions. Problems related to the high drop-out rate in each semester have become a problem in every AMCF Ma'had in Indonesia. Based on the results of interviews with the student affairs section at Ma'had, information was obtained that a large problem that was the trigger was caused by low student learning motivation. Management at Ma'had has made efforts to improve the system in order to reduce the high drop-out rate of students in each semester by conducting regular awareness and socialization, monitoring and changing academic policies. One of the actions is that all new students must make the fact of integrity to be truly serious about learning and achieving academic achievement at least even though they are not perfect (jayyid). The next stage is to give special attention and guidance to students who are considered slow in the learning process by providing assistance from students who have the ability to teach and master Arabic material well from higher semester students.

\section{Curriculum management}

Development of curriculum and syllabus requires people who are professional in their field. Therefore Ma'had must cooperate and coordinate with educational institutions that have the best curriculum in learning Arabic and Islamic Studies, in this case the Arab Islamic Sciences Institute (LIPIA). Among the advantages of this curriculum and lecture system are the use of Arabic as the language of instruction, based on the Qur'an and hadith, and oriented to four basic language skills, namely listening skills (Maha>ratul Istma>), speaking skills (Maha>ratul Kala>m), reading skills (Maha>ratul Qira>'ah), and writing skills (Maha>ratul Kita $>b a h$ ).program curriculum I'da>d Lugawy (language preparation) is oriented to linguistic aspects, especially Arabic.

The Book of Muqorror Genealogy Ta'limm al-Lugah al-'Arabiyyah (hereinafter referred to as the Genealogy Book) is a book with an integrated approach to teaching Arabic which is supplemented by principle material in Islamic studies. Muhammadiyah education is a modern Islamic education that integrates religion with life and between holistic faith and progress. From the womb of Islamic education which was born to this generation of educated Muslims who were strong in their faith and personality, and were able to face and answer the challenges of the times. This is advancing Islamic education. With Muhammadiyah's basic and 
broad educational philosophy, the Al-Islam Kemuhammadiyahan (AIK) course must reflect the perspective that crosses it. The contents of AIK education are knowledge about Islam both normative and historical aspects. The main material of AIK Education has covered five aspects: the Quran \& Hadith, Aqeedah, Akhlak, Fiqh, and Kemuhammadiyahan (Muhammadiyah Teachings).

\section{Learning management}

The learning system implemented in Al-Birr college (Ma'had) at the University of Muhammadiyah Makassar uses classical and non-classical systems. Basically the presence of a classical system is motivated by the desire to apply equally between religious knowledge and general knowledge in educational activities among Muslims. However, for Ma'had as an institution of cadre formation, it remains focused on conducting special religious studies, both classical and modern studies. The adoption of the classical system is more on the renewal of the curriculum and learning methodology, stated by the deputy director (Mudir) of women, that in the learning process in class, Ustadz uses learning methods that provide opportunities for students to express themselves.

Recitation of the book as tradition is one of the most important elements of the existence of an Islamic educational institution. The excavation of Islamic cultural treasures through the acquisition of this book is what distinguishes it from other educational institutions. Al-Birr college (Ma'had) at the University of Muhammadiyah Makassar as an Islamic education institution which has a role as the center of transmission and dissemination of Islamic sciences, especially those that are classic studies (yellow book). So for Al-Birr college (Ma'had) at the University of Muhammadiyah Makassar, there is no doubt that the teaching of the yellow book is absolutely necessary. The yellow book recitation program, which is one of Ma'ad's advantages in accordance with the aim of Ma'had's establishment, is to produce cadres of scholars who understand Arabic.

The results of previous studies conducted by Mujizatullah (2018) on Ma'had Al-Birr explained that the yellow book recitation system carried out at Al-Birr college (Ma'had) at the University of Muhammadiyah Makassar aims to improve understanding (al-fahm) of the text book , practice (al-tatbīq) and student habituation (al-ta'wīd). The learning method used is the method of lecture halāqah, and dan qirä'ah wa al-tarjamah. The factors that influence the process of learning success are clerical competence, student motivation, complete facilities and a conducive environment.

\section{Management of facilities and infrastructure}

Provision of adequate facilities and infrastructure must be supported by a conducive educational environment to help students learn fast and fun. The process of procuring facilities and infrastructure in Ma'had is carried out based on procedures established by AMCF, namely applying for funding and budget based needs to the education coordinator. The facilities and infrastructure owned by Ma'had are currently sufficient and can be used for the learning process effectively and efficiently. However, based on the explanation from the director Ma'had (Mudir) who stated that the challenges faced by ma'had in the management of facilities and infrastructure were maintenance of existing facilities must be managed properly. It takes a high commitment from the management of Ma'had to involve the entire academic community in maintaining and maintaining educational facilities and facilities together even though there have been special staff prepared in the maintenance and procurement of educational facilities. 


\section{Financial management}

Financing in Ma'had consists of incoming and outgoing funds. Funds come from students, the AMCF Foundation and other sources that are lawful and non-binding. Outgoing funds consist of operational funds for implementing educational programs consisting of salaries and incentives, learning programs and activities, maintenance of facilities and procurement of goods and services. The AMCF Treasurer stated that every financial process and financing must be recorded and recorded in the report and audited according to the applicable financial accounting administration system standards with the provisions of financial accountability reports at the end of each academic year and submitted to AMCF supervisors and administrators and the University of Muhammadiyah Makassar. The financing usage accountability report contains the balance sheet, income loss and cash flow along with the explanation. Financing accountability is an integral part of internal and external quality assurance systems. Funding must be in accordance with the accounting information system (SIA) and operating system procedures (SOP) imposed by AMCF treasurers including inputs, processes and outputs, follow-up plans and audits carried out every semester by the AMCF treasurer in accordance with applicable regulations.

\section{SWOT Analysis to understand Management of Institutions}

Al-Birr College (Ma'had) at the University of Muhammadiyah Makassar has implemented institutional management in order to maintain superior and competitive quality. Based on the description of ma'had's institutional management system, it shows that in general the institutional management process consisting of program planning, organizing, implementing, and evaluating programs has been carried out in accordance with existing management standards. There are several main factors that indicate success in ma'had institutional management, namely: (a) management of transformational leadership, (b) qualifications of professional and moral teachers, (c) balanced number of teachers and students, (d) atmosphere conducive work and learning, (e) management of constructive learning, (f) transparent and accountable financial management, $(\mathrm{g})$ procurement and management of good facilities and infrastructure. The results of the SWOT analysis and evaluation results related to the implementation of the management of Ma'had institutions show that there are still many internal problems that must be addressed by the Ma'had managers who have been given the mandate to carry out their duties and responsibilities in accordance with the expected management system. The managerial steps directed by donors to be implemented are Focusing on the quality of work, mandate in work is the responsibility of each individual, not wasteful in using funds as needed. Able to make priority scale and focus on realizing it quickly and completely. Learn from mistakes and work earnestly to find solutions and make them a reference for the future. Making quality and innovation in work.

\section{Al-Birr college (Ma'had) Institutional Transformation Process}

Institutional transformation at Al-Birr college (Ma'had) at the University of Muhammadiyah Makassar cannot only be done on macro aspects (organizational and unit level) without touching the micro aspect (individual level) from the behavior of individuals in the organization. Especially when these changes involve big things, such as the vision, mission, strategy, and design of the overall organizational structure. Williamson, O. E. (2000) analyzes the institutional transformation in four levels, namely institutional transformation at the social level, formal institutional level, level of governance and continuous change. Ma'had as a dynamic educational institution, whose existence is expected by the Foundation to always change and adapt to changes that occur in the organizational environment, especially at the University of Muhammadiyah Makassar. Al-Birr college (Ma'had) at the University of Muhammadiyah Makassar as an education and da'wah organization is expected to be able to 
transform into a learning organization in producing ulama cadres at the University of Muhammadiyah Makassar.

The aim of education was in line with Muhammadiyah's ideal mission as a reference for his business and movement. namely (1) upholding monotheism which is purely based on the Koran and Sunnah, (2) disseminating and advancing (practicing) Islamic teachings sourced from the Qur'an and al-Sunnah al-Shahihah (al-maqbulah), (3) realizing Islam in personal life, family and community. Then ma'had organizational structure and leadership is an integral part of the organization at the University of Muhammadiyah Makassar which places ma'had as one of the technical education implementing units regulated in the University statutes and a collaborative MoU between the AMCF and Muhammadiyah Central Leaders. Personnel development is a necessity in human resource management, because it can improve the performance of personnel that leads to increased product quality and quantity. Likewise, the development of education personnel (educators and non-educators) is important, because these efforts can improve the quality of the education service process which will later lead to improving the quality of educational output. The concept of human resource development includes several important steps namely performance assessment, needs analysis, program planning and program implementation. Performance appraisal is intended to understand the quality of the work of personnel, and the performance assessment of educators can provide a picture of the quality of services provided by certain educators.

\section{Output of Al-Birr College}

Institution Transformation (Ma'had) at the University of Muhammadiyah Makassar The active communication system of the management of Ma'had in the process of institutional transformation is one of the successes of the university in collaborating with AMCF so far. This success makes the University and Al-Birr college (Ma'had) the main reference for PTM leaders throughout Indonesia as one of the management models of ma'had which has the best synergistic relationship among other people in Indonesia. The indicators of success are that some PTM leaders visited the campus in the context of a comparative study of PTM and Al-Birr college (Ma'had) cooperation patterns at the University of Muhammadiyah Makassar.

The AMCF Director stated that one aspect of Ma'had's success in managing institutional ma'had was the ability of the leadership of Ma'had to formulate and transform the vision and mission into a real work that had an impact on all stakeholders of Ma'had. The institutional transformation of Ma'had has had a great impact on the ma'had missionary movement in the community. The role of the alumni ma'ad, the role of students, the role of management and the role of the AMCF Foundation together with the University of Muhammadiyah Makassar in supporting each program carried out at the end have produced remarkable results in realizing the cadre regeneration program. Ma'had as an educational institution has human resources (da'i) who play an active role in teaching and fostering people studying Al-Islam as a true teaching based on the Qur'an and as-Sunnah through religious education programs that are integrated with the education of aqidah, morals and worship correct.

\section{IMPLICATIONS}

Optimizing program integration and productive institutional collaboration between Al-Birr college (Ma'had) and Muhammadiyah University Makassar independently through decentralization of policies and authority to the leaders of Al-Birr college (Ma'had) in strategic decision making in the field of Education and preaching. Strengthening ma'had institutional capacity namely organizational resource capacity and institutional management capacity. The capacity of resources is infrastructure, technology, finance, and human resources. Management capacity includes planning, goal setting, determining responsibility, leadership, allocating 
various resources, motivating and supervising human resources, and maintaining relationships with organizational networks.

This capability is measured from five aspects, namely planning program, management and organizing, staffing, leadership strategy used (implementing), financing, controlling and relationships with external parties namely towards institutional partners, government and donors. Optimizing the role of alumni and da'i ma'had in fostering community in the field of education and da'wah as a form of moral responsibility and community service through improving the quality of the implementation of strategic programs namely preaching and sending programs, markaz tahfidz al quran program, study programs Ahwal Syaksiyah and KPI and the Education program for Tarjih Muhammadiyah Ulama (PUTM). This strategic program cannot be achieved without maximum effort from the management of Al-Birr college (Ma'had) at the University of Muhammadiyah Makassar to innovate and transform programs that are in accordance with the needs of the community and institutions.

\section{DISCUSSIONS}

Implementation of Al-Birr college (Ma'had) institutional management at the University of Muhammadiyah Makassar in aspects of leadership management, educators and education, student affairs, curriculum, learning systems, infrastructure and financial systems, has fundamentally and substantively achieved organizational goals effectively and efficient. This institutional management system produces a unique management design in managing educational and da'wah institutions as an educational model oriented to philanthropy or charity. The management of ma'had institutions is generally carried out centrally and autonomously. Management of the community in an autonomous and centralistic manner is the process of concentration of authority and decision making carried out independently and centralized by AMCF management. The aim of centralizing ma'had policy is for the institutional management system to achieve optimal service and effective solutions for education providers in Al-Birr college (Ma'had) with maximum efficiency.

Control of the Al-Birr college education program (Ma'had) is carried out based on AMCF policies, procedures (SOP) and supervision that are guided by the central management system (CMS). Management has a role as program implementer at AMCF leadership policy. This centralization system facilitates the AMCF leadership in managing all aspects related to academic and non-academic issues in a management system that is applied as a whole AMCF Community in Indonesia. Based on the findings of the centralized system research, it has weaknesses, namely the bureaucratic process and the long time of decision making, but on the other hand the implementation of the program must be completed quickly. The AMCF management role is actively involved in the implementation of leadership management, management of teaching staff, curriculum, maintenance of educational facilities and supervision of the financial system ma'had. The institutional management of Al-Birr college (Ma'had) with a centralized and autonomous management system based on the results of the SWOT analysis shows that this pattern is still very effective implemented on the consideration that the management system has not been managed independently and is still financially dependent on the policies of the founders and donors AMCF. However, the AMCF leadership needs to consider giving more autonomy to the people and encouraging participatory decision making that involves the entire population of Al-Birr college (Ma'had) (the leader of Al-Birr college (Ma'had), head of the University of Muhammadiyah Makassar, asatidz, students, parents and the community).

The basis of the consideration is that you know more about the strengths, weaknesses, and threats that exist in themselves so that you can optimize all available resources in making 
decisions and solving problems quickly and precisely. The process of institutional transformation continues in accordance with the vision, mission, goals, organizational structure, and organizational culture. The process of transforming institutional institutions of Al-Birr college (Ma'had) started from its inception in 1996 until now with the achievement of outputs and educational outcomes that were very satisfying. Based on the results of the study, the purpose of Ma'had's education is very relevant to the vision and mission of the University of Muhammadiyah Makassar, namely to become a leading, superior, trustworthy and independent Islamic tertiary institution in 2024. The mission is to improve faith and devotion, develop creative learning processes, innovative, effective and fun, superior and competitive, developing entrepreneurship based on partnerships and ukhuwah and improving the quality of life and life of the academic community, alumni and society. The output of Al-Birr college's institutional transformation (Ma'had) produces alumni and preachers who play an active role in providing guidance and community service. Al-Birr college (Ma'had) alumni are spread throughout Indonesia. In general, Ma'had alumni serve as da'i (Mubaligh), lecturers, entrepreneurs, politicians, establish da'wah institutions, educators in schools, Ma'had, pesantren, and as public servants (ASN). Profession as a muballig (preacher) is a very noble work because it has a central role in the midst of community life, to continue the prophetic message of al 'ulama'u waritsatul an biya. The role of da'i is very important in guiding and fostering communities in remote areas, especially in improving religious understanding.

\section{References}

Amin, Kamaruddin. (2016). Improving the Culture of Quality and Strengthening the Uniqueness of Education High School of Islamic Boarding Schools, Workshop on Developing Ma'had 'Al-Aly, organized by Research Center for Religious and Religious Education Research and Development and Research and Training of the Ministry of Religion in Bandung, 5 October.

Arsyad, Azhar. (2012) Principles of Management: Practical Knowledge for Leaders and Executives, Yogyakarta: Student Library.

Ary, D., Jacobs, LC, Sorensen, C., \& Razavieh, A. (2010). Introduction to research in education eight edition. Wadsworth: Cengage Learning.

Azra, A. (1999). The Transmission of Al-Manar's Reformism to the Malay-Indonesian World: The Cases of al-Imam and al-Munir. Studia Islamika, 6 (3).

Azra, A. (2012). Islamic Tradition Education and Modernization in the Middle of the Millennium Challenge. Jakarta: Kencana Prenada.

Bungin, B. (2009). Sociology of communication. Prenada Media Group.

Du Preez, P., Simmonds, S., \& Verhoef, AH (2016). Rethinking and researching transformation in higher education: A meta-study of South African trends. Transformation in Higher Education, 1 (1), 1-7.

Efendi, N. (2014). Change management in Islamic boarding schools. Yogyakarta: Terrace.

Hafidhuddin, D. (1998). Actual Da'wah. Gema Insani.

Hardiansyah, D. (2010). Application of the 7E Learning Cycle Learning Model to improve critical thinking skills and mastery of the concepts of high school students. Learning_with cycle model discipline. learning_cycle

Idham, Muh. Sadli Mustafa. (2016). The Ulema Cadre Pattern in South Sulawesi (study on the Ma'had 'A> Program ly Sengkang As'adiyah Islamic Boarding School and Mangkoso Barru Islamic Boarding School Islamic Boarding School. Report on Research Results in the Field of Literature and Religious Treasures, Makassar Research and Development Center.

Ismail, R. "al-Faruqi \& Lois Lamya al-Faruqi. (2003). The Cultural Atlas of Islam Iu, Rusliana (2018). Progressing Cadres, Suara Muhammadiyah, Edition 07 Th. 103, 1-15 April. 43.

Kasali , R. (2006). Change / SC. Gramedia Main Library.

Manzūr, I. (2003). Lisan al-'Arab, vol. Tt: Dār Șādir. Mastuhu. (1994). Dynamics of pesantren education system: a study of the element and value of the pesantren education system, 
Inis Muchtar, MI (2016) Analysis of the concept of hermeneutics in the alquran, hunafa: Journal of Studia Islamika, $13(1), 67-89$

Mudassir, M. (2016) Development of Educational Resources In the District of Bireun District, the scientific journals are practiced: Media Scientific Education and Teaching, 16 (2), 255-272.

Mujizatu llah. (2018). The Kitab Kuning Recitation System in Ma'had Al-Birr Unismuh Makassar, Desertation, UIN Alauddin Makassar, 116-213.

Muljono, Domopolii. (2011). IMMIM Modern Islamic Boarding School Print Modern Muslim. Cet.I .: Jakarta Press Release.

Nayoan, SJ, \& Mandey, JC (2011). Transformation as a Design Strategy. Mattress Media, 8 (2).

Nurhadi, Mulyani A (2003). Effective Management System to Support Educational Quality in the Climate of Decentralization. Semarang: UNNES Postgraduate Program Semarang,

Perdana, NS (2015). Character Education Model Based on Education in Islamic Boarding School. EDUTECH, 14 (3), 402-422.

Rama, B. (2003). Study of Sengkang As' adiyah Islamic Boarding School in South Sulawesi, Cet. I; Central Jakarta: PT. Parodatama Wiragemilang.

Ramayulis, IPI (2008). Kalam Mulia.

Rusdinana. (2016). Development of Educational Institution Organizations. Mold.pertama Bandung: Loyal Library.

Senge, PM (1990). The art and practice of learning organization.

Senge, PM (1991). The fifth discipline, art and practice of learning organizations. Performance Instruction, 30 (5), 37-37.

Suharto, T., \& Shaleh, AQ (2006). Philosophy of Islamic Education. Ar-Ruzz.

Supaat, S. (2011). Transformation of madrasas in the national education system. Journal of Educational Research and Evaluation, 15 (1), 155-186.

Syafrilenti. (2006). Application of Learning Organization at the Regional Secretariat of Siak Regency, Riau Province. Unpublished thesis PSIA PPS UR. Syarif, M. (2013). Theory and Model of Institutional Development of Islamic Higher Education. Media Akademika, 28 (3).

The Holy Quran, Al Raad 13.11

The Holy Quran, Al-An'am 6.165

The Holy Quran, Ali Imran, 3: 110

Uphoff, N. (1986). Local institutional development: an analytical sourcebook with cases. Kumarian Press.

Williamson, O.E. (2000). New institutional economics: taking stock, looking ahead. Journal of economic literature, 38 (3), 595-613. 